\title{
PENGARUH LINGKUNGAN KERJA, MOTIVASI DAN KOMPETENSI TERHADAP KINERJA PEGAWAI KANTOR PERTANAHAN KABUPATEN PONOROGO
}

\author{
Woody Jauhari Rosyid ${ }^{1}$ \\ Nugroho Mardi W. ${ }^{2}$ \\ C. Sri Hartati ${ }^{3}$ \\ Program Magister Manajemen \\ Universitas Wijaya Putra Surabaya ${ }^{1}$ \\ email:woodyjr35@gmail.com
}

\begin{abstract}
This study aims to describe the work environment, motivation, competence and performance of employees in the Ponorogo Regency Land Office. To analyze the influence of the work environment on employee performance. To analyze the influence of motivation on employee performance. To analyze the influence of competence on employee performance. The population in this study were all employees in the Land Office of Ponorogo Regency as many as 93 people. A sample of 93 people with a sampling technique using a type of non-probability sampling, namely total sampling (census). Data collection techniques using questionnaires and documentation. The data analysis technique used is multiple linear regression. The results obtained from this study are the work environment is in a fairly good category, work motivation, competence and employee performance are in good categories. The work environment has a significant effect on employee performance in the Ponorogo Regency Land Office. Work motivation does not have a significant effect on employee performance in the Ponorogo Regency Land Office. Competence has a significant effect on employee performance in the Ponorogo Regency Land Office.
\end{abstract}

Keywords: Work Environment, Motivation, Competence and Performance.

\section{PENDAHULUAN}

Sumber daya manusia (SDM) memiliki dan memegang peran yang penting untuk mencapai tujuan organisasi. Oleh karena berbagai organisasi maupun institusi dituntut untuk lebih memperhatikan untuk melakukan pengelolaan terhadap SDM sebaik mungkin karena SDM juga mempunyai peran yang penting dalam menopang kinerja organisasi ataupun institusi yang ada di Pemerintahan khususnya pada Kantor Pertanahan Kabupaten Ponorogo.
Apalagi dengan persaingan dalam dunia kerja yang semakin meningkat membuat organisasi ataupun institusi lainnya semakin terpacu untuk dapat terus melakukan peningkatan kinerja SDMnya.

Kinerja pegawai dapat ditingkatkan dengan pengelolaan SDM yang baik, lingkungan yang ada di tempat kerja menjadi satu dari sekian banyaknya faktor yang berperan dalam meningkatkan kinerja pegawai karena kinerja yang dimiliki 
oleh pegawai menjadi kunci organisasi untuk maraih kesuksesan.

Oleh karena itu pada setiap organisasi ataupun instansi dituntut untuk mempunyai lingkungan baik dimana lingkungan tersebut dapat memperlancar kelangsungan kerja pegawai sehingga kinerja pegawai dapat meningkat. Berdasarkan pada hasil dari penelitian yang dilakukan Ferawati (2017) menyebutkan bahwa adanya pengaruh dengan arah yang positif dan juga signifikan pada lingkungan terhadap kinerja pegawai. Mashudi, dkk. (2020) juga menyebutkan adanya pengaruhdengan arah yang positif dan juga signifikan pada lingkungan sebagai variabel bebas terhadap kinerja karyawan. Mudayana dan Suryoko (2016) juga menyebutkan ada pengaruh signifikan antara variabel lingkungan kerja terhadap kinerja pegawai. Hasil penelitian tersebut berbeda dengan hasil penelitian Logahan, dkk. (2017) yang menyebutkan tidak adanya pengaruh yag signifikan dari lingkungan kerja terhadap kinerja pegawai. Dari hasil beberapa penelitian yang telah disebutkan di atas ditemukan research gap dari penelitian terdahulu.

$$
\text { Lingkungan kerja juga }
$$

menjadi satu dari sekian banyak faktor yang digunakan dalam peningkatan kinerja pegawai, dengan tersedianya lingkungan kerja bagi pegawai yang baik dan dapat memberikan rasa senang kepada pegawai akan menjadikan pegawai tersebut merasa lebih dihargai sehingga mereka akan merasakan kesenangan dalam bekerja. Lingkungan kerja juga dapat terbentuk dari komitmen pegawai dalam bekerja untuk dapat menyelesaikan segala pekerjaan yang menjadi tanggung jawabnya. Komitmen tersebut dapat muncul dari kemampuan pimpinan dalam menentukan kebijakan di lingkungan kerja tersebut sehingga dibutuhkan juga sikap yang profesional pada penyelesaian tanggung jawab pada organisasi tersebut

Kondisi lingkungan kerja di Kantor Pertanahan Kabupaten Ponorogo dapat dikatakan masih kurang memadai, terlalu banyak berkas dan kurangnya ruang arsip. Ingkungan kerja dapat diartikan sebagai segala yang ada di sekitar tempat pegawai tersebut bekerja, dimana dapat memberikan pengaruh kepada pegawai tersebut dalam melaksanakan tuga yang diberikan kepadanya (Nitisemito, 2015:182). Menurut Mangkunegara (2017:98) lingkungan kerja dapat meningkupi kejelasan jabatan, autoritas bisa memadai, tantangan target pekerjaan, komunikasi yang dilakukan, keharmonisan hungan kerja, kedinamisan iklim kerjais, adanya peluang terhadap karir pekerjaan, dan tersedianya fasilitas yang dapat menunjang pekerjaan.

Selain lingkungan kerja, ada lagi faktor yang bisa digunakan untuk mendorong terhadap peningkatan kinerja SDM yaitu dengan meningkatkan motivasi pegawai dalam bekerja, seperti dengan memenuhi kebutuhan pegawai yang bersifat internal maupun kebuthan pegawai yang bersifat eksternal. Perlu adanya kesadaran bahwa seorang yang diangkat sebagai pegawai yang bekerja pada organisasi atau instansi tertentu adanya untuk pemenuhan akan kebutuhannya sehari-hari atau untuk mencukupi kebutuhan ekonomi maupun kebutuhan lainnya. Hal 
tersebut dapat tercapai dengan adanya pemberian gaji yang diterima tipa periode waktu tertentu, dimana haltersebut dapat menjamin keberlangsungan kehidupan keluarganya. Selain itu juga kebutuha pegawai tersebut akan perkembangan karir dalam hal untuk dapat mengaktualisasikan segala potensi dan kemampuna yang dimiliki. (Robbins and Timothy, 2016).

Berhasil dan tidaknya kerja pegawai tak lepas dari peran motivasi kerja pegawai. hal ini dikarenakan motivasi kerja pada dasarya merupakan faktor yang sangat menentukan berhasil tidaknya pegawai tersebut dalam menjalankan tugas yang telah diberikan kepadanya. Pegawai yang memiliki kompetensi yang berkualitas dan motivasi kerja yang tinggi tentu akan berpengaruh pada kinerjanya. Motivasi kerja pegawai dapat terbentuk dari bagaimana pegawai dalam menyikapi suatu pekerjaan yang ada. Kondisi dimana pegawai tersebut dapat menggerakkan dan mengarahkan dirinya dalam mencapai tujuan dari organisasi ataupun dapat dikatakan tujuan kerja pegawai. Motivasi kerja di Kantor Pertanahan Kabupaten Ponorogo dapat dikatakan masih rendah karena ditemukan masih banyaknya pegawai yang bermalasan sehingga terlihat lebih banyak santainya dari pada bekerjanya, selain itu ditemukan juga pegawai yang lebih mementingkan keperluan pribadnya dari pada untuk kepentingan yang ada di Kantor Pertanahan Kabupaten Ponorogo Hasil penelitian Mashudi, dkk. (2020) Motivasi Kerja (X1) sebagai variabel bebas berpengaruh positif dan signifikan terhadap kinerja kerja karyawan. Mudayana dan Suryoko
(2016) juga menyebutkan adanya pengaruh yang signifikan dari motivasi kerja terhadap kinerja karyawan. Orocomna, dkk. (2018) juga menyebutkan adanya pengaruh yang positif dari Motivasi terhadap kinerja karyawan. Akan tetapi hasil penelitian tersebut berseberangan dengan penelitian Adha, dkk. (2019) yang menyebutkan motivasi kerja tidak mempunyai pengaruh terhadap kinerja karyawan. Dari hasil beberapa penelitian yang telah disebutkan di atas ditemukan research gap dari penelitian terdahulu.

Selain lingkungan kerja dan motivasi kerja pegawai, kompetensi yang dimiliki pegawai juga dapat meningkatkan kinerja pegawai karena kompetensi mempunyai peran yang sangat pentin. Jika kompetensi kerja pegawai bisa menjadi lebih baik maka pekerjaan dapat terselesaikan dengan efektif dan efisien, kualitas pekerjaannya akan menjadi lebih baik, kuantitas pekerjaan yang dihasilkan juga akan semakin banyak sehingga tujuan dapat lebih cepat tercapai. Akan tetapi kompetensi pegawai di Kantor Pertanahan Kabupaten Ponorogo masih belum sesuai dengan pekerjaan yang dilaksanakan karena kebanyakan pegawai yang ada adalah lulusan SMA yang merupakan teman dari PPNPN. Hasil penelitian Mudayana dan Suryoko (2016) menyebutkan variabel kompetensi mempunyai pengaruh yang signifikan terhadap kinerja karyawan. Lestari, dkk. (2018) menyebutkan bahwa Compensation has positive and significant impact to Employee Performance. Kurniawan, dkk. (2018) menyebutkan bahwa competence have a positive effect on employee performance. Hasil penelitian tersebut berbeda 
dengan hasil penelitian Dhermawan, dkk. (2017) yang menyebutkan kompetensi berpengaruh tidak signifikan terhadap kinerja pegawai. Dari hasil penelitian terdahulu tersebut terjadi perbedaan hasil penelitian (research gap), Mudayana, Lestari, dkk. (2018) dan Kurniawan, dkk. (2018) menyebutkan bahwa kompetensi kerja pegawai memiliki pengaruh signifikan terhadap kinerja sedangkan Dhermawan, dkk. (2017) menjelaskan pada hasil penelitian yang dilakukan kompetensi tidak mempunyai pengaruh yang signifikan pada variabel kinerja.

\section{TINJAUAN PUSTAKA}

Kinerja pegawai yang dijelaskan oleh Mangkunegara (2017:67) menyebutkan bahwa hasil kerja yang baik secara kuantitas maupun kualitas dapat dicapai oleh seseorang dalam mengerjakan tugas yang dibebankan kepadanya dengan penuh tanggung jawab. Bangun (2014:233) menjelaskan dalam rangka mempermudah penilaian hasil kerja pegawai, standar kerja dapat diukur dan dilakukan pemahaman dengan jelas terlebih dahulu. Kinerja pegawai dapat diukur melaui beberapa indikator diantaranya:

1. Kuantitas hasil pekerjaan, kuantitas pada setiap hasil pekerjaan pegawai mencakup seberapa banyak jumlah pekerjaan yang bisa diselesaikan bagi orang maupun sekelompok orang yang suda menyesuaikan dengan standart pekerjaan.

2. Kualitas hasil pekerjaan, adapaun kualitas hasil kerja pegawai mencakup setiap pekerjaan yang diselesaikan harus dapat memenuhi persyaratan kualitas pekerjaan tertentu yang telah ditetapkan sebelumnya

3. Tepat waktu, seberapa banyak waktu yang diperlukan dalam menyelesaikan pekerjaan dengan setiap pekerjaan yang memilki perbedaaan karakteristik dan jenis tertentu sehingga bisa juga memerlukan tindak khusus dalam penyelesaiannya

4. Kehadiran, pada pekerjaan tertentu akan menuntut pegawai hadir dan mengerjakan sesuai dengan waktu pekerjaan yang telah diberikan

5. Sikap kooperatif, suatu pekerjaan yang tidak bisa hanya dikerjaan oleh satu orang saja, tetapi pada jenis pekerjaan tertentu menuntuk penyelesaian pekerjaan dengan melibatkan beberapa orang. Dengan demikian sikap pegawai dalam mengikuti pekerjaan tersebut perlu mendapat perhatian dari kemampuan pegawai tersebut untuk melakukan kerja sama dengan pegawai lainnya.

Lingkungan kerj menurut penjelasan dari Nitisemito (2015:183) adalah segala yang berada pada sekitar pegawai, dimana hal tersebut dapat memberikan pengaruh terhadap pegawai dalam melaksanakan setiap tugas yang telah dibebankan kepadanya. Sedarmayanti (2017:28) menjelaskan mengenai indikatorindikator yang dapat digunkan dalam mengukur lingkungan kerja diantaranya:

1. Penerangan atau pencahayaan, penerangan yang ada di tempat kerja yang dapat membantu pegawai dalam melaksanakan pekerjaan dan jga dapat memperlancar pegawai dalam melaksanakan pekerjaan apabila penerangan tersebut dilakukan pengaturan dan penyesuaian 
dengan kebutuhan mayoritas pegawai, karena dengan adanya penerangan yang kurang atau berlebihan akan mengganggu pegawai dalam bekerja sehingga akan sulit dalam mencapai tujuan yang diinginkan organisasi

2. sirkulasi udara, sirkulasi udara yang ada di tempat kerja sangat penting bagi kelancaran metabolism tubuh, apabila udara yang terserap ke dalam tubuh tidak sehat atau bercampur dengan gas tertentu akan menggangguu kelancaran pegawai dalam bekerja.

3. Kebisingan, kebisingan ditempat kerja seperti adanya bunyi-bunyian yang dapat menggu konsentrasi pegawai dalam bekerja bahkan dapat merusak pendengaran pegawai.

4. Bau-bauan, bau-bauan yang tidak sedap ditempat kerja merupakan peganggu pegawai dalam bekerja karena termasuk dalam pencemaran udara

5. Hubungan kerja pimpinan dengan bawahan, adanya komunikasi yang baik saling menghormati dan kepatuhan pegawai terhadap pimpinan di tempat kerja

6. Hubungan kerja sesama rekan kerja, adanya hubungan yang baik dapat memperlancar dan mempermudah penyelesaian masalah dalam tim kerja

Motivasi kerja seperti yang dijelaskan oleh Hasibuan (2016:95) merupakan suatu faktor penggerak seseorang dalam memunculkan gairahnya dalam bekerja supaya dapat melakukan kerja sama, dapat bekerja dengan efektif dan efisien serta dapat mengintegerasikan segala upayahnya dalam memuaskan dalam melaksanakan pekerjan. Adapun indikator yang dapat digunakan dalam mengukur motivasi kerja dengan menggunakan hierarti kebutuhan Maslow yang dikutip oleh Daft dalam Wuwungan, dkk. (2017:300) yang kemudian diturunkan menjadi beberapa indikator seperti

1. Kebutuhan fisik yang merupakan sebagai kebutuhan dasar dasar menusia seperti kegairahan dalam bekerja, keleluasan ruang gerak di tempat kerja.

2. Kebutuhan keamanan, yang merupakan kebutuhan akan keamanan dan ketenteraman pegawai yang terlindung dari segala macam yang dapat membahayakan pegawai dalam bekerja dan upaya penanganan dalam memberika rasa aman kepada pegawai

3. Kebutuhan sosial, yang merupakan kebutuhan untuk bersosialisasi dengan sesama rekan kerja ataupun pada kelompok tersentu.

4. Kebutuhan penghargaan, yang meruakan kebutuhan yang berhubungan dengan segala bentuk penghargaan, pengakuan dan juga apresiasi dari seseorang mengenai hasil kerja yang telah dicapai.

5. Kebutuhan beraktualisasi diri, yang merupakan kabutuhan pemenuhan diri dalam pengembangan potensi secara maksimal

Menurut Wibowo (2016:271) kompetensi adalah kemampuan yang dimiliki seseorang dalam melaksanakan berbagai pekerjan yang telah dibebankan dengan mengerahkan seluruh keterampilan maupun pengetahuan yang telah dimiliki dalam menyelesaikan tuntutan pekerjaan. Menurut Gordon dalam Sutrisno (2016:204) ada berbagai aspek yang dapat digunakan 
sebagai indikator dalam mengukur kompetensi kerja pegawai

1. Pengetahuan yang dimiliki

2. Pemahaman dalam pekerjaan

3. Keterampilan dalam bekerja

4. Nilai perilaku

5. Sikap dalam bekerja

6. Minat untuk melakukan pekerjaan

\section{METODE PENELITIAN}

Metode penelitian ini tergolong penelitian yang berjenis penelitian penjelasan atau istilahnya explanatory research serta dengan pendekatan penelitian kuantitatif. Populasi pada penelitian ini diambil dari semua pegawai yang bekerja pada Kantor Pertanahan Kabupaten Ponorogo yang berjumlah 93 orang. Dengan jumlah sampel penelitiaan juga sebesar 93 orang karena teknik yang digunakan dalam penetian untuk mengambil sampel penelitian dengan Non probability sampling atau sama halnya dengan total sampling (sensus). Teknik pengumpulan data menggunakan kuesioner dan dokumentasi. Teknik analisis data yang dipakai adalah regresi linier berganda (multiple regression).

\section{HASIL DAN PEMBAHASAN \\ Hasil Analisa Deskriptif Variabel Penelitian}

Berikut adalah tabel mengenai hasil jawaban responden dalam menjelaskan independen variable yang meliputi lingkungan, motivasi dan kompetensi maupun dependen variable yang meliputi kinerja pegawai di Kantor Pertanahan Kabupaten Ponorogo.

Tabel 1

Descriptive Statistics

\begin{tabular}{lrrrrr}
\hline \multicolumn{1}{c}{ Variabel } & N & Minimum & Maximum & Mean & $\begin{array}{c}\text { Std. } \\
\text { Deviation }\end{array}$ \\
\hline Lingkungan & 93 & 1.50 & 4.17 & 3.2076 & .41093 \\
\hline Motivasi & 93 & 3.00 & 4.20 & 3.7032 & .31431 \\
\hline Kompetensi & 93 & 2.50 & 4.50 & 3.5309 & .38363 \\
\hline Kinerja & 93 & 2.20 & 5.00 & 3.8581 & .57603 \\
\hline
\end{tabular}

Sumber : Hasil Penelitian, 2021 (diolah)

Berdasarkan Tabel 1 mengenai deskripsi variabel lingkungan dan motivasi serta kompetensi maupun kinerja pegawai di Kantor Pertanahan Kabupaten Ponorogo dapat diketahui bahwa lingkungan kerja dengan mean atau rata-rata 3.2076 dalam kategori cukup baik, motivasi kerja dengan mean atau rata-rata 3.7032 dalam kategori baik, kompetensi dengan mean atau rata-rata 3.5309 dalam kategori baik dan kinerja pegawai dengan mean atau rata-rata 3.8581 dalam kategori baik.

\section{Analisis Regresi Linier Berganda}

Teknik analisisa data dari hasil kuisioner yang diisi responden memakai multiple regression atau yang biasa disebut analisis regresi linier berganda. Analisa regresi ini dipakai oleh peneliti guna melakukan pengujian hubungan dan pertautan antara lingkungan dan motivasi serta kompetensi terhadap kinerja pegawai Kantor Pertanahan Kabupaten Ponorogo, Berikut adalah tabel mengenai hasil uji regresi linier berganda. 


\section{Tabel 2}

Uji Regresi Linier Berganda

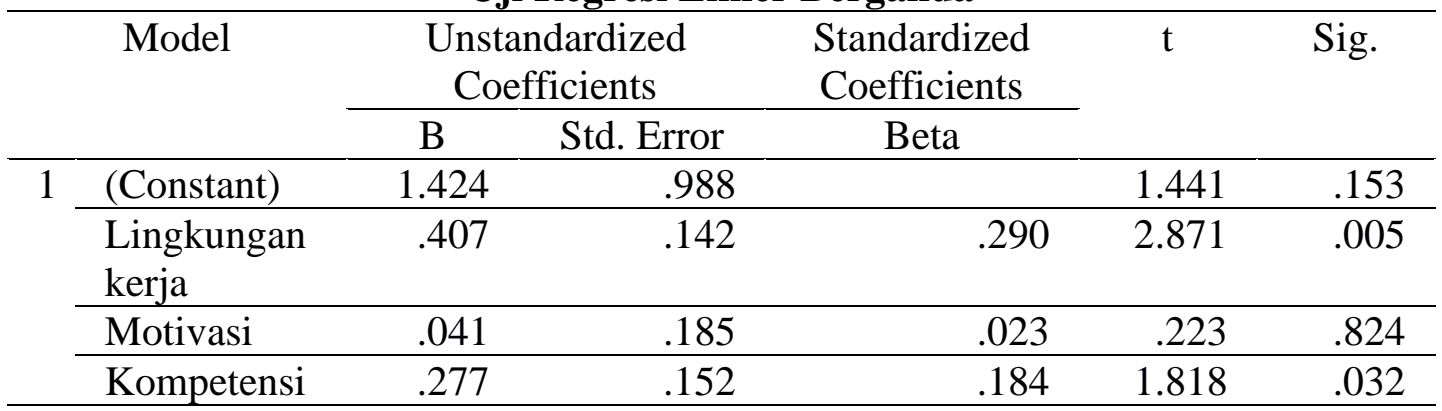

a. Dependent Variable: Kinerja

Sumber : Hasil Penelitian, 2021 (diolah)

Berdasarkan Tabel 2 maka dapat dibuat persamaan regresi linier berganda yang dirumuskan sebagai berikut:

$$
\begin{gathered}
\mathrm{Y}=1.424+0.407 \mathrm{X}_{1}+0.041 \mathrm{X}_{2}+ \\
0.277 \mathrm{X}_{3}
\end{gathered}
$$

Persamaan regresi linier berganda tersebut dapat dijelaskan bahwa Konstanta 1.424 berarti bahwa apabila tidak ada variabel lingkungan kerja, motivasi dan kompetensi maka besaran kinerja pegawai yang ada di Kantor Pertanahan Kabupaten Ponorogo adalah 1.424 satuan. Pada hasil dari persamaan regresi di atas juga dapat diketahui besarnya koefisiensi (B) untuk variabel $\mathrm{X}_{1}$ adalah 0.407, hal ini menandakan bahwa jika lingkungan di tempat kerja naik satu satuan, secara otomatis kinerja pegawai yang ada di Kantor Pertanahan Kabupaten Ponorogo akan meningkat sebesar 0.407 satuan. Pada hasil dari persamaan tersebut di atas dapat diketahui besarnya koefisiensi
(B) untuk variabel $\mathrm{X}_{2}$ adalah 0.041 , ini berarti bahwa apabila motivasi naik satu satuan, maka kinerja pegawai Kantor Pertanahan Kabupaten Ponorogo akan meningkat sebesar 0.041 satuan. Pada hasil analisis regresi linier berganda dalam persamaan tersebut di atas juga dapat diketahui besarnya koefisiensi (B) pada variabel $\mathrm{X}_{3}$ adalah 0.277 , ini berarti bahwa apabila kompetensi naik satu satuan, maka kinerja pegawai Kantor Pertanahan Kabupaten Ponorogo akan meningkat sebesar 0.277 satuan.

\section{Koefisien Determinasi}

Dalam mengetahui seberapa besar kemampuan ariabel bebas untuk dapat menerangkan variabel terikatnya dapat digunkan uji koefisien determinasi atau yang biasa disimbolkan $\left(\mathrm{R}^{2}\right)$. Berikut adalah penjelasan mengenai pengujian dari koefisien determinasi yang tersaji pada tabel berikut.

Tabel 3

Hasil Pengujian Koefisien Determinasi

\begin{tabular}{lcccc}
\hline Model & $\mathrm{R}$ & $\begin{array}{c}\mathrm{R} \\
\text { Square }\end{array}$ & $\begin{array}{c}\text { Adjusted R } \\
\text { Square }\end{array}$ & $\begin{array}{c}\text { Std. Error of } \\
\text { the Estimate }\end{array}$ \\
\hline 1 & $.517^{\mathrm{a}}$ & .267 & .246 & .45471 \\
\hline a. Predictors: (Constant), Kompetensi, Motivasi, Lingkungan \\
\hline \multicolumn{5}{c}{ Sumber : Hasil Penelitian, 2021 (diolah) }
\end{tabular}


Pada Tabel 3 tersebut, maka dapat dijelaskan bahwa $\mathrm{R}^{2}$ yang bernilai 0.267 , dengan hasil tersebut dapat dijelaskan bahwa sebesar $26.7 \%$ variabel kinerja pegawai di Kantor Pertanahan Kabupaten Ponorogo dapat diterangkan oleh variabel lingkungan dan motivasi serta kompetensi. Kemudian sisanya sebesar $73.3 \%$ kinerja pegawai di Kantor Pertanahan Kabupaten Ponorogo dapat diterangkan oleh variabel lain selain variabel lingkungan dan motivasi serta kompetensi.

\section{Uji t}

Berdasarkan hasil analisis data yang dilakukan seperti yang sudah tersaji pada Tabel 2 dapat diketahui nilai untuk $\mathrm{t}$ hitung pada variabel lingkungan adalah sebesar 2.871 yang memiliki tingkat signifikansi 0.005 , dari hasil tersebut nilai signifikansi variabel lingkungan masih $<0.05$, maka Ha diterima dan Ho ditolak. Hal ini berarti bahwa variabel lingkungan kerja mempunyai pengaruh yang signifikan terhadap kinerja pegawai di Kantor Pertanahan Kabupaten Ponorogo.

Berdasarkan pada Tabel 2 menunjukkan bahwa, nilai t hitung untuk variabel motivasi sebesar 0.223 dengan tingkat signifikansi sebesar 0.824 , karena nilai signifikansi $>$ dari 0.05, maka Ho diterima dan $\mathrm{Ha}$ ditolak. Hal ini berarti bahwa variabel motivasi tidak mempunyai pengaruh yang positif dan signifikan terhadap kinerja pegawai di Kantor Pertanahan Kabupaten Ponorogo.

Berdasarkan pada Tabel 2 menunjukkan bahwa, nilai t hitung untuk variabel kompetensi sebesar 1.818 dengan tingkat signifikansi sebesar 0.032, karena nilai signifikansi < dari 0.05 , maka $\mathrm{Ha}$ diterima dan Ho ditolak. Hal ini berarti bahwa variabel kompetensi mempunyai pengaruh yang positif dan signifikan terhadap kinerja pegawai di Kantor Pertanahan Kabupaten Ponorogo.

\section{Pembahasan}

Lingkungan kerja merupakan segala yang berada pada sekitar pegawai, dimana hal tersebut dapat memberikan pengaruh terhadap pegawai dalam melaksanakan setiap tugas yang telah dibebankan kepadanya (Nitisemito, 2015:183). Lingkungan kerja di Kantor Pertanahan Kabupaten Ponorogo dalam kategori cukup baik. Dari hasil analisis regresi didapatkan bahwa konstanta lingkungan kerja bernilai positif dan dari uji hipotesis menggunakan uji t didapatkan bahwa lingkungan kerja mempunyai pengaruh yang signifikan terhadap kinerja pegawai di Kantor Pertanahan Kabupaten Ponorogo, sehingga dapat dikatakan bahwa apabila ada peningkatan pada lingkungan kerja maka akan meningkatkan kinerja pegawai secara signifikan, demikian juga kebalikannya, apabila ada penurunan pada lingkungan, kinerja pegawai juga akan mengalami penurunan yang signifikan.

Motivasi merupakan suatu faktor penggerak seseorang dalam memunculkan gairahnya dalam bekerja supaya dapat melakukan kerja sama, dapat bekerja dengan efektif dan efisien serta dapat mengintegerasikan segala upayahnya dalam memuaskan dalam melaksanakan pekerjan (Hasibuan, 2016:95). Motivasi kerja di Kantor Pertanahan Kabupaten Ponorogo dengan kategori baik. Tidak adanya pengaruh yang positif dan signifikan antara variabel motivasi terhadap 
kinerja pegawai di Kantor Pertanahan Kabupaten Ponorogo. Dari hasil analisis regresi didapatkan bahwa konstanta motivasi bernilai positif dan dari uji hipotesis menggunakan uji $\mathrm{t}$ didapatkan bahwa motivasi tidak mempunyai pengaruh yang signifikan terhadap kinerja pegawai di Kantor Pertanahan Kabupaten Ponorogo. Sehingga dapat dikatakan bahwa apabila ada peningkatan pada motivasi maka kinerja pegawai akan meningkat karena masih bernilai positif, akan tetapi peningkatan tersebut tidak signifikan, begitu juga sebaliknya, apabila ada penurunan motivasi maka kinerja pegawai juga akan mengalami penurunan akan tetapi penurunan tersebut tidak signifikan. Motivasi kerja tidak mempunyai pengaruh signifikan terhadap kinerja pegawai karena pegawai sudah merasa terpenuhinya keinginan untuk berhubungan antar pegawai lainnya, keikutsertaanya dalam kelompok kerja dan memiliki dapat berhubungan baik dengan pimpinan, selain itu juga pegawai sudah terbiasa mendapatkan pengakuan dan pujian atas kontribusinya dalam bekerja di Kantor Pertanahan Kabupaten Ponorogo.

Kompetensi merupakan suatu kemampuan yang dimiliki seseorang dalam melaksanakan berbagai pekerjan yang telah dibebankan dengan mengerahkan seluruh keterampilan maupun pengetahuan yang telah dimiliki dalam menyelesaikan tuntutan pekerjaan. (Wibowo, 2016:271). Kompetensi pegawai di Kantor Pertanahan Kabupaten Ponorogo memiliki pengaruh dengan arah yang positif serta signifikan dengan variabel kinerja yang dimiliki pegawai di
Kantor Pertanahan Kabupaten Ponorogo. Dari hasil analisis regresi didapatkan bahwa konstanta kompetensi bernilai positif dan dari uji hipotesis menggunakan uji $t$ didapatkan bahwa kompetensi memiliki pengaruh yang signifikan dengan kinerja yang dimiliki pegawai di Kantor Pertanahan Kabupaten Ponorogo, sehingga dapat dinyatakan bahwa apabila ada peningkatan pada kompetensi maka kinerja pegawai akan mengalami peningkatan dengan signifikan, begitu juga sebaliknya, apabila ada penurunan kompetensi maka kinerja pegawai turun dengan signifikan.

\section{SIMPULAN DAN SARAN Simpulan}

Dari hasil analisis tersebut di atas, maka penulis bisa membuat kesimpulan antara lain :

1. Lingkungan kerja dalam kategori cukup baik, motivasi kerja, kompetensi dan kinerja pegawai dalam kategori baik.

2. Lingkungan kerja berpengaruh signifikan terhadap kinerja pegawai di Kantor Pertanahan Kabupaten Ponorogo.

3. Motivasi kerja tidak berpengaruh signifikan terhadap kinerja pegawai di Kantor Pertanahan Kabupaten Ponorogo.

4. Kompetensi mempunyai pengaruh yang signifikan terhadap kinerja pegawai di Kantor Pertanahan Kabupaten Ponorogo.

\section{Saran}

Berdasarkan pada kesimpulan dari hasil penelitian yang telah dilakukan, maka penulis dapat memberikan saran kepada berbagai pihak yang terkait sebagai berikut :

1 Hendaknya lebih memperhatikan lingkungan kerja pegawai terutama 
pada jalinan komunikasi, sikap menghormati dan kepatuhan pegawai dengan pimpinan. Selain itu hubungan antara rekan kerja juga perlu untuk lebih diperhatikan, sehingga kerja sama dalam tim dapat berjalan dengan baik.

2 Selain pada lingkungan kerja perlu juga perhatian pada kompetensi pegawai terutama pada peningkatan minat pegawai dalam melakukan pekerjaan dan pengetahuan pegawai tentang cara melakukan identifikasi dan bagaimana melaksanakan pekerjaan yang baik dan benar sesuai dengan kebutuhan yang ada di Kantor Pertanahan Kabupaten Ponorogo.

3 Peneliti selanjutnya yang ingin meneliti tentang kinerja pegawai di Kantor Pertanahan Kabupaten Ponorogo diharapkan dapat memberikan tambahan ataupun mengganti variabel selain dari yang digunakan pada penelitian ini karena masih ada sebesar $73.3 \%$ kinerja pegawai di Kantor Pertanahan Kabupaten Ponorogo dapat dipengaruhi selain dari lingkungan dan motivasi serta kompetensi.

\section{DAFTAR PUSTAKA}

Adha, Risky Nur; Qomariah, Nurul ; dan Hafidzi, Achmad Hasan. 2019. Pengaruh Motivasi Kerja, Lingkungan Kerja, Budaya Kerja Terhadap Kinerja Karyawan Dinas Sosial Kabupaten Jember. Jurnal Penelitian IPTEKS Vol 4, No 1 (2019)
Bangun, Wilson. 2014. Manajemen Sumber Daya Manusia. Jakarta: Erlangga.

Dhermawan, Anak Agung Ngurah Bagus; Sudibya, I Gde Adnyana; dan Utama, I Wayan Mudiarthan. 2017. Pengaruh Motivasi, Lingkungan Kerja, Kompetensi, Dan Kompensasi Terhadap Kepuasan Kerja Dan Kinerja Pegawai Di Lingkungan Kantor Dinas Pekerjaan Umum Provinsi Bali. Jurnal Manajemen, Strategi Bisnis, dan Kewirausahaan Vol. 6, No. 2 Agustus 2017

Ferawati, Apfia. 2017. Pengaruh Lingkungan Kerja Dan Lingkungan kerja Kerja Terhadap Kinerja Karyawan. AGORA Vol. 5, No.1, (2017)

Hasibuan, Malayu S.P. 2016. Manajemen Sumber Daya Manusia. Edisi. Revisi. Jakarta: Penerbit PT Bumi Aksara.

Kurniawan, Donatus Adi; Guswandi; and Sodikin, Akhmad. 2018. The Effect Of Competence And Motivation On Employee Performance Through Employees Capabilitieson PT. Binasinar Amity.

Lestari, Setyani Dwi; Syabarudin, Dindin A.; Zurnali, Cut; and Murad, Dina Fitria. 2018. The Influence of Work Environment, Competence and Compensation on Employee Performance 
Journal of Applied Management and Accounting Science. (JAMAS)

(Woody Jauhari Rosyid, Nugroho Mardi W., C. Sri Hartati 93 - 103)

Vol 2, No 2, Juni 2021

through Intervening Variable

Job Satisfaction at Bank BJB

Tangerang

Branch.International Journal of Academic Research in Business and Social Sciences. Vol. 8 , No. 11, Nov, 2018, E-ISSN: $2222-6990$ C 2018 HRMARS

Logahan, Jerry M.; Tjoe, Tjia Fie; dan Naga. 2017.Analisis Pengaruh Lingkungan Kerja Dan Pemberian Kompensasi Terhadap Kinerja Karyawan CV. MUM Indonesia. Binus Business Review Vol. 8 No. 1 Mei 2017: 573-586

Mangkunegara, A.A. Anwar Prabu. 2017. Manajemen Sumber Daya Manusia Perusahaan. Bandung : Remaja Rosdakarya.

Mashudi, Imron; Wijiyanti, Ratna; dan Bahtiar Efendi. 2020. Pengaruh Motivasi Kerja Kelingkungan kerjaan Kerja Dan Lingkungan Kerja Terhadap Kinerja (Studi Kasus pada Karyawan PT. Bank BRI Tbk. Kantor Cabang Kabupaten Wonosobo).

Mudayana, Fansyuri Ilham dan Suryoko, Sri. 2016. Pengaruh Kompetensi, Kompensasi, dan Lingkungan Kerja terhadap Kinerja Karyawan melalui Motivasi Kerja Sebagai Variabel Intervening (Studi Kasus pada Karyawan Bagian Produksi PT. Sai Apparel Industries Semarang) Jurnal
Ilmu Administrasi Bisnis Vol 5(1) 2016

Nitisemito., Alex. 2015. Manajemen Sumber Daya Manusia: Bandung: Pustaka setia

Orocomna, Cion; Tumbel, Tinneke M.; and Asaloei, Sandra Ingried. 2018. Pengaruh Motivasi Kerja Terhadap Kinerja Karyawan Pada PT. Taspen (Persero) Cabang Manado Jurnal Administrasi Bisnis Vol. 7 No. 1 Tahun 2018

Robbins, Stephen P., and Timothy A. Judge. 2016. Perilaku Organisasi Edisi 16. Jakarta : Salemba Empat.

Sedarmayanti. 2017. Manajemen Sumber Daya Manusia. Bandung: Refika. Aditama

Wibowo. 2016. Manajemen kinerja. Jakarta: Rajawali Pers. Wirawan. 2015. Manajemen Sumber Daya Manusia Indonesia. Jakarta: PT. Raja Grafindo Persada.

Sutrisno, Edy. 2016. Manajemen Sumber Daya Manusia, Kencana Prenada. Jakarta: Media Group.

Wuwungan, Ronna Yulia; Taroreh, Rita N.; dan Uhing, Yantje. 2017. Pengaruh Lingkungan Kerja Dan Motivasi Kerja Terhadap Kepuasan Kerja Karyawan Cinemaxx Lippo Plaza Manado. Jurnal Emba. Vol.5 No.2 Juni 2017, Hal. 298 - 307. 